\title{
Learning Pattern of Speaking Subject in Higher Education: A Constructiveness Review as Educational Innovation
}

\author{
Ngatmini $^{1}$, Rustono ${ }^{2}$, Subyantoro ${ }^{3}$, Mimi Mulyani ${ }^{4}$ \\ ${ }_{1,2,3,4}$ Graduate School, Universitas Negeri Semarang, Indonesia \\ ${ }^{1}$ Corresponding email: ngatminingatmini3@gmail.com
}

\begin{abstract}
A number of research finding results indicated that students' speaking ability is still below average. It is highly estimated, that the trigger was students' lack confidence, lack of understanding toward material, and lecturers less communicative. This study captured up learning patterns conducted in four different universities. The learning patterns were then reviewed from constructivism approach, for each learning pattern certainly assist students and enables them integrating their knowledge from the lesson learned. Because of that, students can speak fluently since they have both concept and experience making them to become more confident. This is a qualitative study, the data was taken by observation, interview, and documentation. The classroom discourse data were analysed by using Miles and Huberman's interactive models. The results found that the learning pattern of speaking subject at those studied universities dominated by lecturers. Lecturer was the one who initiates, inspires, asks, and evaluates. Lecturers have not succeeded in developing critical thinking skills, students only respond, correspond, and answer questions for clarification and confirmation. Lecturers were often called Teacher Talking Time (TTT) instead of Student Talking Time (STT). The average score of students' speaking subject was 76 .
\end{abstract}

Keywords: learning pattern, speaking, universities.

\section{Introduction}

Education is a conscious and deliberate effort to change human behaviour individually or in groups through learning and training efforts. In the interaction between students, interaction between lecturer and students, and collaboration between the two ( $\mathrm{Su}$ et al., 2005). Interaction is quite important element in learning achievement and even becomes a key to learning process. As was emphasized by Brown (no year) 'interaction is the core of communication, between students and lecturer(s) communicate each other. However, in reality an interaction between students and with lecturer(s) proved below average. This is because their speaking competence remains insufficient, as Dewantara (2012) pointed out that most learners found themselves confronting with lack of speaking skills due to their passive and difficult attitude toward the speaking subject. Similarly, Untoro (2011) and Astuti (2014) argued in their research that students have lack of speaking ability when they were given a chance. In addition, students declare lack of confidence, lack of understanding toward the materials, and lecturers less communicative. This is due to an instilled paradigm which emphasizes the learning is still on the teaching understanding instead of the learning understanding.
Students can interact on a reciprocal basis if they are able to build a fully and comprehensively understanding of new knowledge. The knowledge already possessed is connected to the new learned knowledge. Thus, the students actually already have their initial knowledge, experience, and various information obtained as a result of their learning. The new knowledge being learned is integrated with the already possessed knowledge which enable them to build selfconcept, be easily understand, analyse, and generate new concepts that can influence the changes in themselves. Because of that, students are able to communicate their ideas to others smoothly and confidently. Students can share knowledge others and help improve the quality of human resources (HR) through speaking skills. Such a learning model was developed by a constructivism thought (Rosyada 2016).

Constructivism is an approach that allows students to construct their own knowledge or new information with the knowledge or experience they have. Bruning et al. (2004 in Schunk, 2012:320) says that in constructivism each individual forms or builds most of what is learned and understood. Students must be provided with facilities in order to learn meaningfully in order to attain their best speaking skills. 
Speaking skill is a skill of producing articulation-sound system flow to convey the will, the need for feelings, and the desire to others (Ahmadi, 1990:19). Meanwhile Nurgiyantoro (2012:397) argued that speaking is an activity of giving and receiving the language, conveying ideas and messages to the other person and at the same time the speaker will receive ideas and messages from his/her interlocutor. These skills are mechanistic, the more they are being practiced the more skilled the practitioners will be (Tarigan, 1998: 43). Speaking is an activity of directly use the language skills. This is closely related to the interactive learning process.

Teachers' learning patterns ideally provide students with opportunity to experience the learning process directly. Through the concept of learning comprehension, lecturers can act as facilitators. Any learning model if it is based on an effective learning understanding, then students can learn significantly. On such a reason, this study overview the learning process occurred in several universities, thus one of highlighted issues is on how the learning pattern of speaking subject at some selected universities in the light of learning constructivism?

\section{Method}

This study applied a descriptivequalitative approach (Moleong, 2000:6, Sugiyono, 2010:15) in addition to using the ethnographic method (Creswell, 2015:ix). Data collection techniques use observation, documentation, and interviews. Researchers are 'objective' observers because observers' record facts, interaction events in the classroom with impartiality. The research design applied classroom discourse analysis. The data was in the form of students and lecturers' conversation, while the data source is lecturers' and students' conversations in teaching and learning interaction of speaking skills at several selected universities. The study sample is several selected universities in Central Java which have Indonesian Language and Literature Education department.

The technique sampling applied a specific purpose, the sample includes 4 universities, they are technically described with code of A, $\mathrm{B}, \mathrm{C}$, and D. The data analysis used interactive models of Miles and Huberman (1992:19), with four research technical stages, data, data reduction, data presentation, and the conclusion or verification of the findings.

\section{Results and Discussion}

The teaching and learning interactional pattern of speaking subjects at four different universities centred on lecturers' roles. A summary of the teaching and learning interactional pattern $i s$ is presented in the following table.

Table 1 illustrates that lecturers seem to dominate and control students in learning. This is in line with Liu \& Le (2012), Husna (2015), Maja's (2015) findings that learning is still dominated by lecturers. In a class, the lecturers and students' roles may never be the same or asymmetrical (Walsh 2011: 24). The lecturers played a major role in managing the class, however, they may not be found much more dominant. However, in the findings, lecturers initially tend to be more speaking out, instructing, inspiring, and ending up the learning.

Of the four universities, there have identical similarities, which is the lecturers constantly initiate the learning activities and give instructions to students. Instruction is dominated by low cognitive level of questions. The instructions are presented in the following chart. 
Tabel 1. Teaching -Learning Interactional Pattern of Speaking Subject at Universities

\begin{tabular}{|c|c|c|c|c|}
\hline Universities & Univ. A & Univ. B & Univ. C & Univ. D \\
\hline Lecturer(s) & 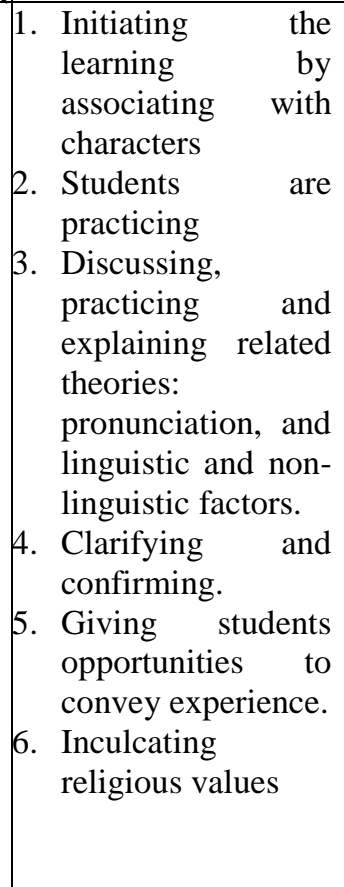 & $\begin{array}{l}\text { 1. Beginning to } \\
\text { telling the story } \\
\text { and clarifying } \\
\text { the } \\
\text { understanding } \\
\text { of the module } \\
\text { through } \\
\text { question and } \\
\text { answer guiding } \\
\text { the students. } \\
\text { 2. Sometimes } \\
\text { getting } \\
\text { involved, } \\
\text { praising or } \\
\text { clarifying } \\
\text { answers or } \\
\text { questions. } \\
\text { 3. Bringing out } \\
\text { the activities } \\
\text { which will be } \\
\text { followed by } \\
\text { students }\end{array}$ & $\begin{array}{l}\text { 1. Giving a warming- } \\
\text { up introduction to } \\
\text { speaking practice } \\
\text { 2. Giving comments } \\
\text { to the practicing } \\
\text { students such as } \\
\text { diction, the } \\
\text { standard and non- } \\
\text { standard words use. } \\
\text { 3. Asking students in } \\
\text { groups to discuss } \\
\text { with the specified } \\
\text { topics. } \\
\text { 4. Accompanying } \\
\text { presentations } \\
\text { occasionally gives } \\
\text { a discussion }\end{array}$ & $\begin{array}{l}\text { 1. Initiating and } \\
\text { confirming the debate } \\
\text { implementation. } \\
\text { 2. Provide guidance on } \\
\text { implementing the } \\
\text { technique running a } \\
\text { debate (determination } \\
\text { of value form, jury, } \\
\text { moderator). } \\
\text { 3. Assisting and } \\
\text { observing the debate. } \\
\text { 4. Observing the process } \\
\text { of implementing the } \\
\text { debate. } \\
\text { 5. Providing discussion, } \\
\text { suggestions and } \\
\text { conclusions. }\end{array}$ \\
\hline Students & $\begin{array}{l}\text { 1. Following the } \\
\text { instruction. } \\
\text { 2. Praciting speaking. } \\
\text { 3. Listening the } \\
\text { lecturer's } \\
\text { explanation. } \\
\text { 4. Answering questios } \\
\text { to clarrifying and } \\
\text { confirming. } \\
\text { 5. Expressing the } \\
\text { experience, coping } \\
\text { with anxiety } \\
\text { followed by } \\
\text { practice }(10 \%)\end{array}$ & $\begin{array}{l}\text { 1. Telling stories } \\
\text { in front of class. } \\
\text { 2. Friends making } \\
\text { simple } \\
\text { comments. } \\
\text { 3. Answering the } \\
\text { lecturer's } \\
\text { questions for } \\
\text { confirmation } \\
\text { and } \\
\text { clarification. }\end{array}$ & $\begin{array}{l}\text { 1. Following } \\
\text { lecturer's } \\
\text { instructions. } \\
\text { 2. Practicing speaking } \\
\text { in front of the } \\
\text { class. } \\
\text { 3. Passively waiting } \\
\text { for practice turn. } \\
\text { 4. Group discussion. } \\
\text { 5. Presentation. } \\
\text { 6. Proposing } \\
\text { referential } \\
\text { questions. } \\
\text { 7. Answering the } \\
\text { questions }\end{array}$ & $\begin{array}{l}\text { 1. Answering the } \\
\text { lecturer's questions on } \\
\text { the preparation of the } \\
\text { debate. } \\
\text { 2. Following the } \\
\text { lecturer's instructions. } \\
\text { 3. Preparing debate } \\
\text { implementers } \\
\text { (moderators, debating } \\
\text { teams, judges, } \\
\text { representatives and } \\
\text { observers). } \\
\text { 4he process of } \\
\text { debating Team Pro, } \\
\text { Counter Team delivers } \\
\text { debate materials and } \\
\text { Jury, class } \\
\text { representatives, and } \\
\text { lecturers submit an } \\
\text { assessment or } \\
\text { response. }\end{array}$ \\
\hline Average Value & 69 & 73 & 79.8 & 83.5 \\
\hline
\end{tabular}




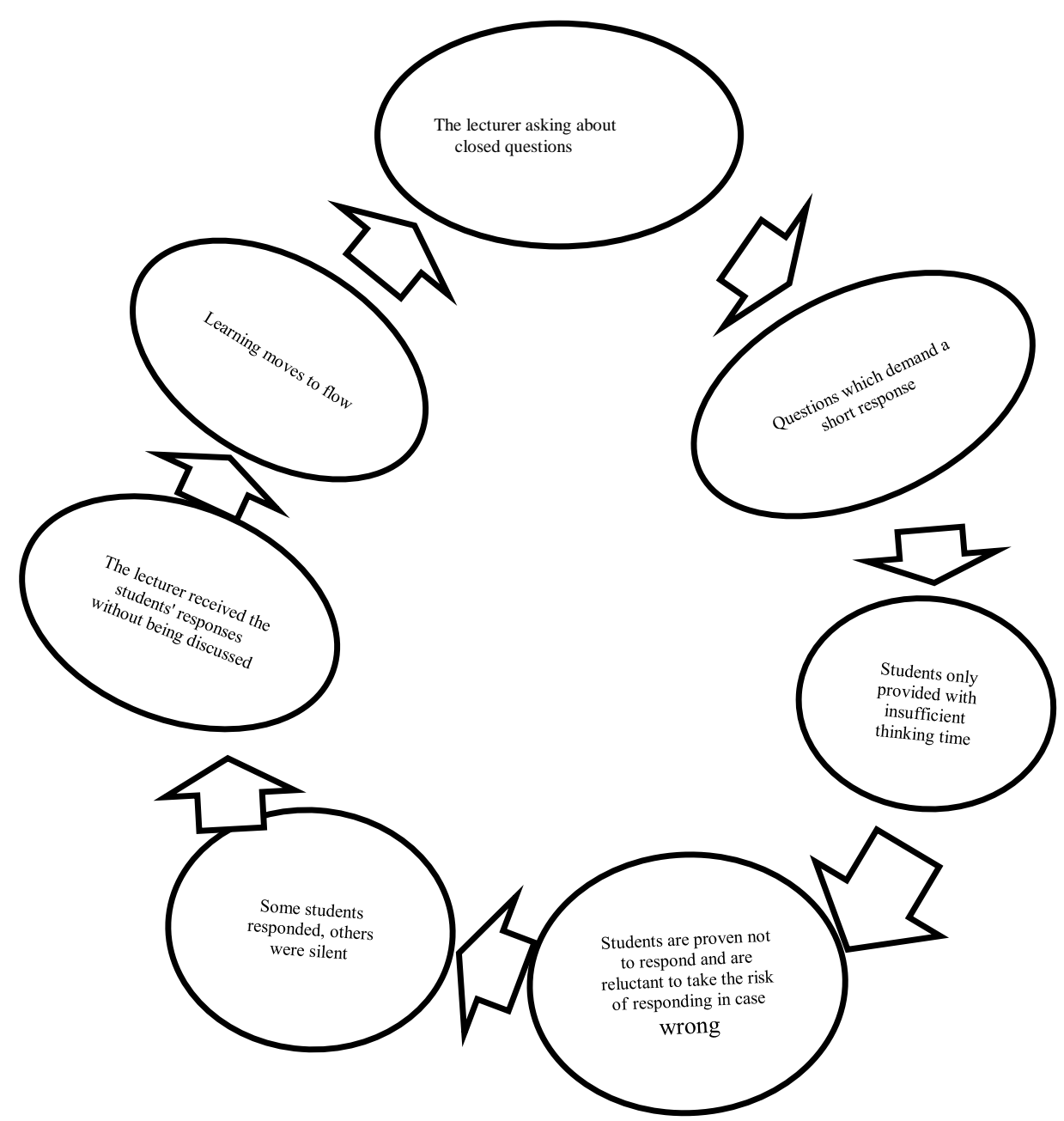

Chart 1. Lecturers' Questions which Prone to Instruct

While the students only responded to the extent that the lecturers requested even in one university, it is found an uncompleted response. The uncompleted response occurs when the lecturers asks students to respond to a student who exercises his speaking skill, the students responded, however, then the lecturers further ask the reason for the response, which was not followed by the student. The lecturers in this case too, does not give the opportunity to think at the given time, not to provide guidance, reference, etc. One of data is elaborated as follows:

\section{CONTEXT:}

SELF-TRAINING

STUDENTS SPEAKING IN FRONT TELLING A STORY ABOUT THE NEW KLINTHING LEGEND.

\section{Lecturer}

$\begin{array}{ll} & \text { "Sudah bagus?" } \\ \text { Students } & \text { : "Lumayan... lumayan...!" } \\ \text { Lecturer } & \text { : "Lumayan dibanding apa?" } \\ & \text { "Baik selanjutnya yang } \\ & \text { kedua siapa yang akan } \\ & \text { maju, tadi katanya } \\ & \text { sukarela lho ya... oke mari } \\ & \text { segera kita manfaatkan } \\ & \text { waktu dengan baik" }\end{array}$

On that piece of conversation, the lecturer asks students to comment on one of their classmate who has finished telling a story in front of the class, but at the end the students have not commented, the lecturer then offered an assessment. The above utterance illustrates that the interaction between students and their interaction with the lecturer remains low. A few moments later the students replied, "'’lumayan ...lumayan!" (Eng. Not bad!) the answer was followed by the lecturer' question on clarrifying the student's opinion, "Lumayan dibanding apa?" (Not bad compared to 
what?"). This question is intended for students to give reasons for their opinions. However, the lecturer did not get any response from the students after waiting a while. Then the lecturer continued the learning by asking the next student's turn to come forward. On the utterance ".... tadi katanya sukarela tho ya ..." [you have just said you will do voluntarily, will you?] this illustrates that the students have not come forward, it is predicatble that the students' interest to learn is less or students are reluctant to talk. Lubis emphasized that students are reluctant to asking beucaseu they are having lack of confidence, lack of mastering the materials, or lecturers are less communicative. In line with that segment, there were found questions clarifying, confirming, and providing guidance or direction.

Questions are key components of class discourse (Chin, 2007:816). Questions can be used as a medium to construct knowledge. Knowledge is built in the social context in the classroom. However, the lecturer and students in that regard should sufficiently master the material and the techniques of asking for questions. Asril (2011) pointed out that basic asking-skills include the following components: clear disclosuring of questions, giving references, centralizing answers, responses, questioning, thinking time, and guidance. The lecturer authorized students in building up their ideas which strategically need to be assisted by establishing questions, exercises, and guidance. Lecturers have not applied activities as applied by common lecturers. The use of principle activity for students, because they seek and direct. Thus, as the students learn, work together, learn according to their interests or developing their own academic abilities.

The learning activities which occurred in four selected universities initially begins by lecturer and the lecturer as students' inspirational figure, on such a reason the learning is controlled by lecturer. In the lesson, the lecturer gives out the material, directions, or instruction. As the lecturer explained the theory then it is followed by questions to confirm or clarify the truth of the theory with the practice that students have undertaken one of the fragments is shown as follows:
CONTEXT: CONVERSATION LECTURER AND STUDENTS WHO DISCUSSED THE STUDENT'S APPEARANCE STYLE (SYIFA) ON PRACTICING SPEAKING AS HOST. THE DISCUSSED TOPIC IS A CAUSE OF ANXIETY CAUSE.

\begin{tabular}{ll}
\hline Lecturer & "Yang pertama, jadi gejala- \\
& gejala kecemasan di depan itu \\
& disebut dengan gejala-gejala \\
& kecemasan berbicara atau \\
& disebut dengan syndrome \\
& mekanisme penyesuaian. \\
& Gejalanya yang pertama \\
& adalah detak jantung terpacu \\
& lebih cepat dari biasanya. Kita \\
& cek Syifa mengalami itu atau \\
& tidak?". \\
\hline Students & "Yaa". \\
Lecturer & "Yang sudah maju kemarin \\
mengalami itu atau tidak?". \\
Lecturer & "Yaa...". \\
& "Kemudian dicek coba telapak \\
& tangannya berkeringat atau \\
tidak? & "Berkeringat.. \\
Students & "Tidak berkeringat". \\
Students & "Berkeringat? Yang lain? \\
Lecturer & Mungkin ada yang \\
& berkeringat ada yang tidak. \\
& Nah, yang ketiga nafasnya \\
& terengah-engah. Kemudian \\
& mulut kering dan sukar \\
& menelan. Hal ini tidak bisa \\
diamati. Syifa merasakan itu & atau tidak?". \\
&
\end{tabular}

The pattern found in the fragment illustrates the pattern of questions with the lecturer-student-lecturer structure (Initiation Response Evaluation) (Chin, 2007:819).Students with such learning patterns have not done critical thinking activities even interactions have not been established. Students can interact otherwise they master sufficient understanding on the material and master the means to communicate. However, after presenting the results of discussion and debate, students asked high-level questions (referentials) which demand the person being quested to provide a highly thinking level of answers. Similarly, in the debate, the parties involved use high-level thinking. Students 
express opinions responded by opposing teams, judges assess, representatives as well, including lecturers. They have experienced the process of building their own knowledge and associating with new knowledge at the same tie. This activity is the target of students studying the speaking subjects, however, among those who can undertake such activities remain minimum in numbers. However, the direction toward learning constructivism already exists. To enhance the interaction, this can be achieved through understanding and mastery of the given materials and making integrated association on the past experience with the material being studied (Mulyasa, 2003:186).

There are lecturers' activities that provide opportunities for students to share experiences, opinions in discussions, and debates. However, the opportunity given by the lecturer has not led the students to think creatively. Creative thinking is one of the educational innovation activities (Ibrahim, 1988). This study also includes one of the educational innovation activities, this is because the findings are used as a reference for learning a good course of speaking. Student competence in learning speaking proved still in the low category, then the solution to the problem can be determined. Based on these facts, the reconstruction of the teaching model will be applied to lecturers, students, learning materials, etc. (Ibrahim, 1988).

In their activities, students tend to follow lecturer's instructions. While Palloff and Pratt (1999) say that the key learning process is the interaction between students, the interaction between faculty and students, and collaboration between the two (cited in Su et al 2005:1). Activities undertaken by students have not been categorized as follow-up learning, because learning activities involve both physical and mental activities that take place in the condition of active interaction with the environment that produces a number of changes. Walsh said (2012:1), a dialogical class is more involved, focusing more on participation that creates class interaction competence. While lecturers still talk a lot (Teacher Talking Time) not Student Talking Time (Cullen, 1998).

When students present material, there are a number of questions that demand critical presenters. The question of 'why', 'how', 'what is the reason' is a referential question. The question is at a high level of cognitive ability. In such situations, both the questioner and the recipient of the question will develop critical thinking. They will think of looking for answers and relating something they have, both experience and knowledge. That's where concept changes occur that can be harmonized with the constructivism approach. This is what is called the process of building new knowledge, students will be fluent in speaking and confident.

In learning with the debate model there is a dialogical situation, in which students grow generative thinking that can become a habit. In a dialogue situation grows questions and connects ideas that are the rationale so that students are active, analytical of ideas. In dialogical discourse like debate, it is necessary to emphasize the knowledge that has been built together (Chin, 2007:2019). Classroom activities determine the outcomes of learning (Lumpkin, 2015:356 in Prilanita and Sukirno 2017).

The achievement of the students on the average of all colleges is 76 . However, from the college studied, the sample is still low, that is 69. This is relevant to the opinion of Good and Brophy (in Hai, 2006) that the verbal behavior lecturers in the class have an effect on student achievement. Similarly, Kiemer et. al., (2015) opinion that the meaningful pattern of lecturer questions provides a good opportunity for students to explore and express their own understanding.

\section{Conclusion}

The learning patterns of speaking subject are overall still dominated and controlled by lecturer(s). Learning paradigm is applying the teaching comprehension, which consequently the learning system remains in lecturercentred learning paradigm. One reflects the interaction through question but the question built is still on the low cognitive level. This has not been able to guide students to thinking critically, let alone developing and building their knowledge with the knowledge learned. This is a proof that among the students are still in low-level of achievement, even their speaking ability remains confronting with obstacles, which are the anxiety, silence, embarrassment or reluctant to express opinions.

The learning model determines the students' thinking pattern, because of that 
reason, the lecturer creates a varied learning model. The learning model is part of the learning system. Learning component should at least supporting each other, therefore, it enables students' achievement get more improved. In light of applying the paradigm of understanding in learning, students should be given more times (Student Talking Time (STT) instead of the lecturers/ Teacher Talking Time (TTT)).

\section{References}

Ahmadi, Mukhsin.1990. Strategi Belajar Mengajar Keterampilan Berbahasa dan Apresiasi Sastra. Malang: YA 3 Malang.

Arsjad, Maidar G dan Mukti US. 1993. Pembinaan Kemampuan Berbicara Bahasa Indonesia. Jakarta: Erlangga.

Asril, Zainal. 2011. Microteaching: disertai Dengan Pedoman Pengalaman Lapangan. Jakarta. Rajawali Press.

Astuti, Ana Eqi, Sunardi, Joko Nurkamto. 2014. Pengaruh Metode Pembelajaran Role Play dan Story Telling Berbantuan Video Terhadap Keterampilan Berbicara Bahasa Inggris Ditinjau Dari Motivasi Belajar.

Brown, H. Douglas. Tt. Teaching by Prinsiple: An Interactive Approach to Language Peadagogy. Second Edition: Longman (diunduh $25 \mathrm{Mei}$ 2015).

Chin, Christine.2007. Teacher Questioning in Science Classrooms: Approaches that Stimulate Productive Thinking. Journal Of Research In Science Teaching VOL. 44, NO. 6, PP. 815843 (2007).National Institute of Education, Nanyang Technological University.

Cullen, Richard . 1998. Teacher Talk And The Classroom Context .ELT Journal Volume 52/3 July (C) Oxford University Press.

Dewantara, I Putu Mas. 2012. "Identifikasi Faktor Penyebab Kesulitan Belajar Keterampilan Berbicara dan Strategi Guru Untuk Mengatasinya Siswa Kelas VII E
SMP N 5 Negara". Artikel Penelitian. Prodi Pendidikan Bahasa. Bali. Ipi259100 kesulitanberbicaradewantara.pdf.Ado be-Reader (diunduh 26 Agustus 2015).

Hai, See Kin and Lim Siew Bee. 2006. "Efectiveness of Interaction Analysis on the verbal Behaviour of Primary School Mathematics Teacher". Jurnal Pendidik dan Pendidikan Jilid 21 (115-128). Department of Science and Mathematics Education, Education Faculty, Universiti Brunei Darussalam. (diunduh 5 Februari 2015).

Hamalik, Oemar. 2009. Proses BelajarMengajar. Jakarta: PT Bumi Aksara.

Husna, Arina Hafadhotul, Rudi Hartono, Ahmad Sofwan.2015. "Teacher's And Students' Talks And Their Nonverbal Communication In The Classroom Interaction”. English Education Journal. http://journal.unnes.ac.id/sju/index.p hp/eej. EEJ 5 (1) (2015)

Ibrahim. 1988. Inovasi Pendidikan. Jakarta: Depdikbud Dirjen Dikti P2LPTK.

Kiemer, Katharina, Alexander Groschner, Ann-Kathrin Pehmer, Tina Seidel. 2015. "Effects of a classroom discourse intervention on teachers' practice and students' motivation to learn mathematics and science". Learning and Instruction 35 (2015) 94e103. Technische Universit€at München, Arcisstraße 21, 80333 Munich, Germany.journal homepage:

www.elsevier.com/locate/learninstru c. (diunduh 30 November 2015).

Liu, Jingxia and Thao Le. 2012. "A Case Study on College English Classroom Discourse". International Journal of Innovative Interdisciplinary Research. Issue (diunduh 1 April 2015).

Lubis. Muzzani.2011. Mengapa Siswa Tidak Mau Bertanya? 
http://www.catatanpendidik.web.id/2 011/10/mengapa-siswa-tidak-maubertanya.html (dinduh 15 Oktober 2015).

Maja, Margaret Malewaneng. 2015. Classroom interaction in teaching English First Additional Language learners in the Intermediate Phase. University Of South Africa (12 November 2016).

Miles, Mathew B. dan A. Michael Huberman. 1988. Analisis Data Kualitatif. Terjemahan Tjejep Rohendi Rohidi. Jakarta: Universitas Indonesia.

Moleong, Lexy J. 1995. Metodologi Penelitian Kualitatif. Bandung: Remaja Rosda Karya.

Nurgiyantoro, Burhan. 2012. Penilaian Pembelajaran Berbahasa Berbasis Kompetensi. Yogyakarta: BPFE.

Nurjanah, Nunuy, 2008. Inovasi Pendidikan Menuju 100 Tahun. Orasi Ilmiah di STKIP Al-Azhar Majalaya pada tanggal 5 Maret 2008

Prilanita, Yeni Nur dan Sukirno. 2017. Peningkatan Keterampilan Bertanya Siswa Melalui Faktor Pembentuknya. Yogyakarta: Cakrawala Pendidikan, Juni 2017, Th. XXXVI, No. 2

Riswani, Elza Firanda \& Ani Widayati Halama. 2012. "Model Active Learning dengan Teknik Learning Starts With A Question dalam Peningkatan Keaktifan Peserta Didik Pada Pembelajaran Akuntansi Kelas $\mathrm{Xi}$ Ilmu Sosial 1 Sma Negeri 7 Yogyakarta Tahun Ajaran 2011/2012”. Jurnal Pendidikan Akuntansi Indonesia, Vol. X, No. 2

Rosyada, Dede. 2016. Pembelajaran Berbasis Penelitian. Jakarta: Journal of Educational Technology. Vol 18 No. 3

Sardiman A.M. 1986. Interaksi \& Motivasi Belajar Mengajar. Jakarta: Grafindo.

Smith, Ian. 2007. Assessment \& Learning. Penerjemah P.A. Lestari. Strategi Penilaian untuk Belajar. Erlangga: Yogyakarta.

$\mathrm{Su}$, Bude, Curtis J. Bonk, Richard J. Magjuka, Xiaojing Liu, and Seunghee Lee. 2005. "The Importance of Interaction in Web-Based Education:

A Program-level Case Study of Online MBA Courses". Indiana University. Journal of Interactive Online Learning. www.ncolr.org. Volume 4, Number 1 Summer 2005. ISSN:1541-4914

https://www.google.co.id/journalteac hingandlearninginteractions

Tarigan, Henry Guntur. 1984. Teknik Pengajaran Keterampilan Berbicara. Bandung: Angkasa

Untoro, Raharjo Dwi. "Analisis Wacana Lisan Interaksi Guru Dan Siswa Di Kelas (Studi Kasus Pemakaian Bahasa Di Sma Negeri 3 Sragen Dalam Mata Pelajaran Bahasa Indonesia, Biologi, Dan Sosiologi)”. Penelitian. http://digilib.uns.ac.id/pengguna.php ?mn=detail\&d_id=14037(diunduh 20 April 2015).

Walsh, Steve. 2011. Exploring Classroom Discourse Language And Action. Routlegde Taylor \& francis grup. London and New York. Bookfi.org. (pdf. Adobe Rider) (diunduh 24 Maret 2015).

Walsh, Steve. 2012. Conceptualising Classroom Interactional Competence. Novitas-ROYAL (Research on Youth and Language), 2012, 6 (1), 1-14. . 